Julia Dynkowska

Wydział Filologiczny

Uniwersytet Łódzki

e-mail: julia.dynkowska@gmail.com

\title{
„A jednak oczyma / [m]oimi patrzycie...". O doświadczeniu sztuki w doświadczaniu przestrzeni
}

Tytułowy cytat został oczywiście zaczerpnięty z wiersza Breughel (II) Stanisława Grochowiaka. Te słowa - jak pisze Adam Dziadek - „[m]ogą [...] oznaczać, że malarz żyje poprzez swój obraz, żyje, by tak rzec, w spojrzeniu widza na obraz" ${ }^{1}$. Wydaje się jednak, że owo triumfalne (choć „wyrzekane” post mortem): „Ja - Malarz - już nie żyję. A jednak oczyma / Moimi patrzycie na śnieg i na wodę / Przyprószoną zaledwie" można spróbować zinterpretować również szerzej, jako refleksję dotyczącą malarstwa Bruegla, tak silnie utrwalonego w kulturze i wyrazistego, że bywa niekiedy swojego rodzaju pryzmatem, przez który ogląda się świat. Wydaje się, że zimowym pejzażom niderlandzkiego twórcy przysługuje w tym względzie szczególna moc.

Patrzenie na przestrzeń „oczyma artysty” nie ogranicza się rzecz jasna do „patrzenia Brueglem”. Filip Lipiński zauważa taką prawidłowość np. w przypadku należących do zupełnie (?) innego porządku dzieł Edwarda Hoppera:

Obrazy te [Hoppera] z jednej strony każą pamiętać o innych obrazach, z drugiej przypominają się $\mathrm{w}$ momencie konfrontacji widza $\mathrm{z}$ innymi dziełami i obszarami wizualności. Słowem, ich widzenie oznacza intensywne, pamięciowe zaangażowanie innego. Wiąże się z tym znaczenie wirtualnego jako swego rodzaju oczekującego na realizację rezerwuaru pamięci, obrazów, wyobrażeń, snów (podkr. - J.D.]².

1 A. Dziadek, Obraz jako interpretant: na przykładzie polskiej poezji współczesnej, „Pamiętnik Literacki" 2001, nr 2, s. 146.

2 F. Lipiński, Hopper wirtualny. Obrazy w pamiętajacym spojrzeniu, Torun 2013, s. 35. 
Korzystając z ustaleń Kai Silverman³, Lipiński nazywa ów rezerwuar pamięci „pamiętającym spojrzeniem" ${ }^{4}$, jest to „spojrzenie oparte na przypomnieniu, będące odpowiedzią na impuls wizualny, intymne, zaglądające na zewnątrz, a jednocześnie do wewnątrz przedmiotu i podmiotu oglądu" ${ }^{5}$. Za taki impuls wizualny prowokujący przypomnienie jakiegoś dzieła malarskiego można prawdopodobnie - oprócz innych obrazów - uznać także obserwowaną przestrzeń (w końcu to również, jak chce Lipiński, „obszar wizualności”).

W artykule chciałabym omówić swoiste "literackie artykulacje zmysłowego (wizualnego) doświadczenia przestrzeni" ${ }^{6}$, w których to właśnie obserwowane otoczenie budzi u podmiotu skojarzenia z malarstwem. Na zdarzenia zachodzące w świecie czy też po prostu - dostrzegane w nim krajobrazy są w tych tekstach "nakładane” przypominające je (wizualnie lub fabularnie) „powidoki” dzieł sztuki czy rozpoznawalnych estetyk rozmaitych twórców. A zatem w tym specyficznym wariancie kulturowej prefiguracji postrzegania przestrzeni, erudycja podmiotu i jego doświadczenia odbioru sztuk pięknych mają wpływ na sposób, w jaki odbiera on otoczenie.

Warto być może dodać, że istnieje jeszcze inny - $\mathrm{w}$ pewnym sensie zbliżony do tego, na którym będę się skupiać - typ utworów opisujących doświadczenia sztuki w doświadczaniu przestrzeni (pomijam go w dalszej części mojego tekstu): zapisy z podróży do miejsc uwiecznianych przez malarzy. Autorzy takich tekstów konfrontują oglądane przez siebie krajobrazy z zapamiętanymi dziełami i sposobami malowania in loco nascendi ${ }^{7}$. W pol-

\footnotetext{
3 Tamże, s. 45.

4 Wspomina też oczywiście o déjà vu (powiązanym u niego z Derridiańskim toujours déjà; tamże, s. 215) i zaznacza, że w Innych obrazach Marii Poprzęckiej pojawia się analogiczne sformułowanie - „obraz pod powiekami” [M. Poprzęcka, Inne obrazy. Oko, widzenie, sztuka. Od Albertiego do Duchampa, Gdańsk 2008, s. 139]. U Elżbiety Rybickiej w podobnym kontekście jest z kolei mowa o „powidokach” [E. Rybicka, Geopoetyka: przestrzeń i miejsce we wspótczesnych teoriach i praktykach literackich, Kraków 2014, s. 259].

5 F. Lipiński, Hopper wirtualny, s. 47.

6 Fragment zaproszenia na konferencję Poetyki doświadczenia przestrzennego (Białystok, 8-9.06. 2017 r.).
}

7 Jeszcze inny wariant to literackie omówienia „wewnętrznych krajobrazów” budowanych często w oparciu o dzieła sztuki przedstawiające internalizowane miejsca, jak np. w przypadku Włoch (które zresztą w końcu odwiedza) Marcela z powieści W poszukiwaniu straconego czasu, zwłaszcza Wenecji i Florencji: „Nie mając miejsca na to, aby w nazwę Florencji wprowadzić elementy, które zazwyczaj składają miasto, musiałem stworzyć sobie miasto nadprzyrodzone, zapładniając pewnymi wiosennymi zapachami to, com uważał za geniusz Giotta w samej jego istocie" [M. Proust, W stronę Swanna, przeł. i wstępem opatrzył T. Boy-Żeleński, Warszawa 1965, s. 493]. O „wewnętrznych krajobrazach” u Marcela Prousta pisze m.in. Hanna Buczyńska-Garewicz [Miejsca, strony, okolice. Przyczynek do fenomenologii przestrzeni, Kraków 2006, s. 1-33 i 253-289]. Sugestywny (i ładny) opis zapośredniczonych i zinternalizowanych krajobrazów 
skiej eseistyce o malarstwie ten przypadek omówiła ostatnio m.in. Dobrawa Lisak-Gębala. Jako jeden z przykładów badaczka podaje - obok esejów Gustawa Herlinga-Grudzińskiego, Zbigniewa Herberta czy Ewy Bieńkowskiej fragment z Podróży do Włoch Jarosława Iwaszkiewicza:

Sam włóczyłem się naokoło San Gimignano w tym bardzo specyficznym pejzażu, pomiędzy gajami oliwnymi, gdzie stały młode oliwki o płomienistych zakończeniach gałązek i wysokie, od połowy pnia dopiero opierzone czarnymi piórami cyprysy. To wszystko na tle złota zalegającego pola lub czerwonej zaoranej ziemi tworzyło tło, które z taką radością odnajdywało się we freskach i obrazach sieneńskiej i florenckiej szkoły ${ }^{8}$.

Co ciekawe, Elżbieta Rybicka właśnie tego typu teksty (również Iwaszkiewicza) uznaje za specyficzny przejaw sensorycznej, a dokładniej rzecz ujmując - wizualnej geografii literackiej. „Literackie reprezentacje krajobrazów percypowanych wzrokowo" - pisze autorka Geopoetyki - „bardzo często dowodzą [...], iż «oko» postrzegającego jest okiem wykształconym, zaznajomionym z malarską tradycją pejzażową [...]" ${ }^{\prime 9}$. To rozpoznanie Rybickiej można jednak z całą pewnością odnieść również do tych utworów poetyckich, którymi chciałabym się zająć.

Pierwszym jest Nic wspólnego ${ }^{10}$ Julii Hartwig. W tym tekście sygnał „zaznajomienia" podmiotu $\mathrm{z}$ tradycją malarską pojawia się już $\mathrm{w}$ pierwszym zdaniu - w porównaniu: „Światło jak z obrazu Friedricha / ale to tylko lasek podmiejski / przecięty brudnym strumieniem przedzierającym się przez wykroty"11. Pozornie zaskakujące zestawienie dzieła romantycznego malarza z banalnością lasku podmiejskiego („nic wspólnego”) pełni tu dość pro-

pojawia się też np. w pierwszej strofie wiersza Jutro, jutro Dereka Walcotta: „Pamiętam miasta, których nigdy naprawdę / nie widziałem. Srebrne żyły Wenecji, cerkwie Leningradu / niczym pagórki toffi. Paryż. Światło utkane / z cienia, które wkrótce wymyśli Manet. Ach, i wężowe sploty uliczek Hyderabadu" [D. Walcott, Jutro, jutro, przeł. P. Marcinkiewicz, w: tegoż, Mapa Nowego Świata. Wiersze wybrane, wybór i red. M. Heydel, Kraków 2008, s. 123].

8 J. Iwaszkiewicz, Podróże do Włoch, cyt. za: D. Lisak-Gębala, Wizualne odskocznie. Wokót wspótczesnej polskiej eseistyki o malarstwie i fotografii, Kraków 2016, s. 78.

9 E. Rybicka, Geopoetyka, s. 259.

10 J. Hartwig, Wiersze wybrane, Kraków 2010, s. 272.

11 Nie da się chyba stwierdzić, który obraz (i czy w ogóle tylko jeden) ma na myśli Hartwig. Być może chodzi tu o Wieczór (1821 r.) lub Las w świetle księżyca (1830 r.); „dwóch rzezimieszków" w lasku podmiejskim przypomina z kolei Dwóch mężczyzn obserwujących księżyc (1824 r.). Jednak pojawiające się w ostatnich wersach "złote” i „porażające” światło wydaje się wykluczać dwa ostatnie tropy. Swoją drogą, to właśnie światło w obserwowanych przestrzeniach niezwykle często prowadzi do zestawienia z malarstwem tego, co zwyczajne czy codzienne. Tak jest np. w Strefie lirycznej Zbigniewa Herberta z pierwszym zdaniem analogicznym do Hartwigowskiego: „Widok na park i mur w przedwieczornym świetle / jak u Corota - skóra cytryny skóra 
stą funkcję wprowadzenia $\mathrm{w}$ przedstawioną $\mathrm{w}$ kolejnych wersach sytuację. Zamglone światło Caspara Davida Friedricha określane jako światło "godzin przed zmierzchem" lub „zimny blask księżycowej pełni" ${ }^{12}$ towarzyszy bowiem w wierszu Hartwig "dwó[m] rzezimieszk[om]" wiodącym „dziewczynę owiniętą w chustę [...] w niezbożnych wcale zamiarach". Ta scena budzi w podmiocie poczucie obcości i sprzeciw: „Jakaś przejmująca groza zjeża skórę na widok tego sparszywiałego człowieczeństwa / jakiś gwałtowny protest". Owa obcość i sprzeciw są rzecz jasna wymierzone przede wszystkim w dostrzeżonych ludzi (podmiot nie ma z nimi „nic wspólnego"), ale ludzi dostrzeżonych $\mathrm{w}$ określonym krajobrazie. Wydaje się zatem, że całą zauważoną scenę można powiązać z mroczną, choć towarzyszącą zazwyczaj wzniosłej scenerii, atmosferą wielu dzieł Friedricha, nie tylko z charakterystycznym światłem jego obrazów. Warto jeszcze odnotować, że zapisane wrażenie zostaje po chwili zatarte (,trwa to tylko ułamek sekundy"): osoba mówiąca obserwuje bowiem przestrzeń i wszystkie zdarzenia przez okno pociągu, a zatem „widzi koleją" (określenie Wojciecha Tomasika) i - co za tym idzie - jej pole widzenia stale ulega zmianie ${ }^{13}$. Tym bardziej, być może, akcentuje się tu wrażliwość podmiotu, który światło widziane przez „ułamek sekundy" (po chwili zmienia się ono bowiem w "przestrzeń zalanych złotem łąk" porażającą "światłem jak zbudzonych po koszmarze" - już bez bezpośrednich odniesień do żadnego twórcy ${ }^{14}$ ) wiąże z manierą Friedricha.

W tym zapisie błyskawicznego rozpoznania pewnych jakości danego na moment wycinka przestrzeni, można dostrzec także cień refleksji Zbigniewa Herberta dotyczącej skontrastowanych z „udręką opisywania” reguł widzenia, „które dają całość w jasnym i nagłym świetle jednoczesnej obecności” 15

policzka z pudrem po balu / powietrze złotolite" [Z. Herbert, Wiersze zebrane, Kraków 2011, s. 672]. „Cytrynowość" kolorystyki Camille'a Corota pojawia się również w À trois paysagistes Théophile'a Gautiera („Zielone niebo ma odcienie cytryny i pomarańczy” [Le ciel vert a des tons de citron et d'orange]) czy w poemacie The Prodigal Dereka Walcotta („Widziałem [...] cytrynowe światło Jean-Baptiste'a Camille'a Corota" [I saw (...) the lemon light of Jean-Baptiste Camille Corot]). T. Gautier, À trois paysagistes, [online] http://www.unjourunpoeme.fr/poeme/a-trois-pay sagistes [dostęp 29.05.2017]; D. Walcott, The Prodigal, [online] http://www.nytimes.com/2004/ 10/31/books/chapters/the-prodigal.html?_r=0 [dostęp 29.05.2017]. Z „malarskim” światłem mamy też do czynienia we fragmencie Gry w klasy: „Maga wzięła lampę i postawiła ją na podłodze, stwarzając nastrój z Rembrandta [...]" [J. Cortázar, Gra w klasy, przeł. Z. Chądzyńska, Warszawa 1998, s. 178].

12 M. Rzepińska, Siedem wieków malarstwa europejskiego, Wrocław 1986, s. 382.

13 W. Tomasik, Ikona nowoczesności. Kolej w literaturze polskiej, Wrocław 2007, s. 190.

14 Choć wśród dzieł Friedricha można odnaleźć również „zalane złotem łąki” - w Pejzażu $z$ tęcza.

15 Z. Herbert, Labirynt nad morzem, Warszawa 2000, s. 19. 
oraz percepcji malarstwa: „wizja malarska jest nagła i dana jak krajobraz ujrzany w świetle błyskawicy"16. A zatem - co dość oczywiste - odniesienie do sztuki, zwłaszcza do konkretnego artysty (najlepiej - konkretnego dzieła) w utworach o przestrzeni pozwala precyzyjniej ją opisać, skraca dystans między postrzegającym a tym, co postrzegane (zarówno między podmiotem i obserwowanym czy komentowanym przez niego światem, jak i - na innym poziomie - czytelnikiem i tekstem, ułatwiając rekonstruowanie sytuacji lirycznej $\left.{ }^{17}\right)$.

Doświadczenie sztuki w doświadczaniu przestrzeni jest zasygnalizowane nieco inaczej niż w Nic wspólnego w innym utworze Hartwig. Chodzi o Zachód Claude'a Lorraine'a ${ }^{18}$. Wydaje się, że w tym przypadku literacka reprezentacja krajobrazu jest jednocześnie ekfrazą grupy dzieł malarza ${ }^{19}$ :

Zachód Claude'a Lorraine'a napotkać można na wszystkich południowych morzach Europy, wszędzie gdzie nieruchoma grupa ludzi spogląda milcząc na rozpostarte statki żaglowe, w smudze umierającego w chwale blasku ${ }^{20}$.

Nie da się bowiem nie zauważyć, że wymienione przez Hartwig - jako właściwe „południowym morzom Europy” - elementy kompozycji pojawiają się na obrazach francuskiego pejzażysty. Maria Rzepińska pisze wszak,

16 Z. Herbert, Martwa natura z wędzidłem, Warszawa 2003, s. 92. Por. J. Przyklenk, Esej podróżniczy jako świadectwo percepcji: na przykładzie eseistyki Zbigniewa Herberta, "Język Artystyczny" 2010, nr 14, s. 93.

17 Rzecz jasna - pod warunkiem, że czytelnik jest zaznajomiony z tymi obrazami lub estetyką, które przywołuje autor.

18 Oxford Dictionary of English dopuszcza również taki zapis przydomku słynnego malarza („Lorraine”), choć o wiele częściej pojawia się forma „Lorrain”. Lorrain Claude, w: Oxford Dictionary of English. Second Edition, Revised [E-BOOK], eds. C. Soanes, A. Stevenson, Oxford 2010.

19 Bywa również, że to, co obserwowane, przywołuje na myśl szereg powidoków obrazów więcej niż jednego twórcy. Dobrym (bo wykorzystującym "obrazy pod powiekami” reprezentatywne dla - wydawać by się mogło - skrajnie różnych estetyk i pochodzące z różnych sztuk) przykładem takiego zestawienia jest fragment Prywatnej historii obrazów i krajobrazów Małgorzaty Baranowskiej: „Fragment Plant o świcie Wyspiańskiego i drzeworyt Utagawy Hiroshige - reprodukcje, list Irenki i Zdzisława Łapińskich, którzy wypuścili się szybką (jak na tutaj) koleją do Krakowa. Nieprawdopodobnie dobrane. Dwa eteryczne i, nie wiadomo dlaczego, zachwycające drzewka poskręcane wiatrem, w ruchu. Gdzie ja coś takiego widziałam, słyszałam, podobne drzewo, drzewa? U Pawlikowskiej-Jasnorzewskiej? Znajduję z Notatek z Bielan. Bez tej siły, co składany krajobraz Słowackiego [z Rozłączenia], ale z tą przemożną chęcią, by w końcu krajobrazy, natura sama czerpała z kultury, żeby wszystko zaczynało się od człowieka, od słowa, od rzeźby, od obrazu. Las naśladowca? «Grupa buków / splata ramiona - / las skopiował jak mógł / Laokoona»" [M. Baranowska, Prywatna historia obrazów i krajobrazy, „Teksty Drugie" 2000, nr 5, s. 185].

${ }^{20}$ J. Hartwig, Wiersze wybrane, s. 38. Po raz kolejny to światło pozwala zestawić przestrzeń $\mathrm{z}$ malarstwem. 
że „[d]o najbardziej udanych i typowych dla niego obrazów należą liczne widoki portów morskich, $\mathrm{z}$ fragmentami architektury, małymi figurkami ludzi [...]. [C]ały środek obrazu wypełnia prześwietlone słońcem mgliste niebo. [...]"21. W przypadku Zachodu Claude'a Lorraine'a (i w przypadku tekstów analogicznych do tego utworu) można zatem dosłownie potraktować uwagę Elżbiety Rybickiej: „krajobrazy naturalne czy cywilizacyjne często postrzegane są $\mathrm{w}$ literackich reprezentacjach jako malarskie pejzaże, sceny $[\ldots]^{\prime \prime 22}$.

Co jednak istotniejsze, odnotowane przez podmiot utworu powtórzenie kompozycji obrazów Lorraina „na wszystkich południowych morzach Europy", a przede wszystkim twórczość malarza budzą skojarzenia z przypomnianym przez Filipa Lipińskiego ( $w$ związku $\mathrm{z}$ "pamiętającym spojrzeniem") Gilpinowskim pojęciem picturesque (malowniczości ${ }^{23}$ ). Lipiński pisze:

Za picturesque [...] były uznawane widoki wyjątkowe, niepowtarzalne, a zarazem powtórzone, bowiem rozpoznane jako widziany wcześniej obraz lub realizacja ściśle określonych efektów stosowanych $\mathrm{w}$ malarstwie. [...] Aby fragment natury wydał się malowniczy, czyli wyjątkowy, jedyny i niepowtarzalny, musi być swoistym cytatem, powtórzeniem już widzianego ${ }^{24}$.

21 M. Rzepińska, Siedem wieków malarstwa europejskiego, s. 279.

22 E. Rybicka, Geopoetyka, s. 258.

23 Malarstwo Claude'a Lorraina - obok twórczości Nicolas Poussina i Salvatora Rosy - uznaje się za modelowe dla wrażliwości picturesque. Uvedale Price w napisanym u schyłku XVIII w. Eseju o malowniczości nazywa tego twórcę „najbardziej dekoracyjnym ze wszystkich wielkich mistrzów dzieł, w porównaniu z jego własnymi prymitywnych i niedoskonałych; choć prawdopodobnie [...] on sprawiłby, że mogłyby mieć «możliwości»" [U. Price, Esej o malowniczości, przeł. B. Frydryczak, w: Krajobrazy. Antologia tekstów, oprac. B. Frydryczak, D. Angutek, Poznań 2014, s. 179]. Denis Cosgrave odnotowuje z kolei, że „Pejzaże Claude'a Lorraina stały się modnym wskaźnikiem bogactwa i statusu społecznego [...], czego dowodem były wysokie ceny oryginałów oraz powszechność i dostępność ich kopii" [D. E. Cosgrove, Krajobraz i europejski zmyst wzroku - przygladanie się naturze, przeł. B. Frydryczak, w: Krajobrazy. Antologia tekstów, s. 94]. Z modną i rozpoznawalną estetyką malarza wiąże się także popularność w osiemnastowiecznej Anglii tzw. „szkiełka Claude'a” (Claude glass, miroir noir), przedmiotu zaskakująco dobrze wpisującego się $\mathrm{w}$ rozważania o roli sztuki w doświadczaniu przestrzeni. Claude glass to niewielkie, wypukłe, zaokrąglone i zabarwione lusterko, które „ujmował[o] w ramy i przyciemniał[o] rzeczywiste widoki” [tamże, s. 94], zamieniając "przyrodnicze sceny w miniaturowy obraz podkreślający ich podobieństwo do pejzaży Claude'a lub przynajmniej do dzieł malarskich" [D. Marshall, The Problem of the Picturesque, "Eighteenth Century Studies" 2002 nr 3, s. 420, http://www.jstor.org/stable/30054207 [dostęp 25.09.2017]]. Omawiane teksty poetyckie można uznać za swoiste literackie Claude glasses eksponujące cechy estetyk konkretnych twórców w „Zwykłej” przestrzeni oglądanej przez podmiot.

24 F. Lipiński, Hopper wirtualny, s. 208-209. 
Świadomość powtórzenia (nawet jeśli niewyrażona wprost) jest zresztą chyba wpisana we wszystkie literackie manifestacje "pamiętającego spojrzenia" i nasuwa pytanie o to, w jakim stopniu i czy w ogóle człowiek może postrzegać przestrzeń bez kulturowych zapośredniczeń ${ }^{25} \mathrm{i}$ „,sztucznych" filtrów (to problem wielokrotnie akcentowany ${ }^{26}$ ).

Zresztą w samo zjawisko picturesque (poszukiwania i oglądania malowniczych przestrzeni) jest przecież wpisany kulturowy dystans. David Marshall w eseju The Problem of the Picturesque zaznacza, że chociaż impuls dla jej dostrzeżenia stanowi zachwyt nad pięknem natury, to malowniczość reprezentuje "punkt widzenia zamykający świat w ramie i zmieniający naturę $\mathrm{w}$ serię tableaux vivants" ${ }^{27}$. Owo "zamknięcie” jest z kolei możliwe właśnie dzięki dystansowi w stosunku do obserwowanych krajobrazów. Kulturowe oddalenie, które, w gruncie rzeczy, prowadzi do banalizowania tego, na co się patrzy, poddaje krytyce David Lowenthal, w stan oskarżenia stawiając przy tym - rzecz jasna - Claude'a Lorraina:

Oswajanie natury, doświadczenie podróży oraz rozwój malarstwa krajobrazowego nauczyły Europejczyków we wczesnej fazie ery nowożytnej patrzenia na świat rzeczywisty jako ciąg statycznych i sztucznych widoków. Claude przyzwyczaił oglądających do traktowania krajobrazu jak obiektu obojętnej kontemplacji - doceniania go jako namalowanego obrazu. Praktyka estetycznej oceny krajobrazu ma swój początek w tej wątpliwie malarskiej spuściźnie ${ }^{28}$.

O ile reprezentacja „pamiętającego spojrzenia” w tekstach Hartwig rzeczywiście jest nieskomplikowana, to wydaje się, że Jacek Dehnel w wierszu Korytarz, późna jesieńn ${ }^{29}$ ukazuje pogłębioną relację „ja” lirycznego i przestrzeni.

Podmiotowi podróżującemu - podobnie jak w pierwszym z omówionych utworów - pociągiem widok z okna: „wierzby”, „głogi i tarniny [...],

25 E. Rybicka, Geopoetyka, s. 259.

${ }^{26}$ Przecząco odpowiadają na postawione pytania m.in. Ryszard Nycz („Widzimy to, co spodziewamy się zobaczyć, wiedza warunkuje (wyprzedza, umożliwia, ogranicza) identyfikację postrzeganego" [R. Nycz, O przedmiocie studiów literackich - dziś, w: tegoż, Poetyka doświadczenia. Teoria - nowoczesność - literatura, Warszawa 2012, s. 28, podkr. - J. D.]) i Denis Cosgrove: „Ludzki wzrok jest intencjonalny i kulturowo uwarunkowany”, „widzenie to aktywność kulturowa” (ale - jak dodaje geograf kultury - „dyslokacja geograficzna lub zmiana kulturowa mogą zakłócić ugruntowane sposoby widzenia, otwierając przestrzeń dla bardziej krytycznej refleksji na temat tego, co postrzegane") [D. E. Cosgrove, Krajobraz i europejski zmyst wzroku, s. 79,82$]$.

27 D. Marshall, The Problem of the Picturesque, „Eighteenth Century Studies” 2002, nr 3, s. 414, http://www.jstor.org/stable/30054207 [dostęp 25.09.2017].

28 D. Lowenthal, Życie z krajobrazem i oglądanie krajobrazu, w: Krajobrazy. Antologia tekstów, s. 111.

29 J. Dehnel, Żywoty równoległe, Kraków 2004. 
z których liście właśnie / opadły, zostawiając obłoki owoców" oraz pora roku przywodzą na myśl obrazy Bruegela („Od rana same Brueghle, bo to późna jesień"). W tym tekście doświadczenie sztuki w doświadczaniu przestrzeni nie ogranicza się jednak tylko do tego, co obserwowane. Rozrasta się, zaczyna obejmować całe otoczenie („gdyby nie jakaś stacja od czasu do czasu, / jakiś blok i bocznica, pociąg by udawał / salę w Kunsthistorisches z zupełnym mistrzostwem") i działania podmiotu: np. otwiera się tu "obrazy", nie okna, a - jak podkreśla Aleksandra Kremer ${ }^{30}$ - „otwarcie brudnej czy zaparowanej szyby" przypomina mu "zdjęcie werniksów i mgieł z oryginalnego ob$\mathrm{razu}^{\prime 31}$. Co więcej, uzupełnia on podziwiane widoki o elementy pojawiające się na płótnach Bruegla: „puścić między te wierzby chłopów z tasakami /

30 A. Kremer, „Patrzeć oczami artysty?”. Dzieła sztuki w wierszach Jacka Dehnela, w: Ars in artibus. Recepcja sztuk plastycznych w muzyce, literaturze i filmie, red. A. Jezierska, D. Maciejewska, Wrocław 2008. Badaczka pisze również o innych tekstach-zapisach "pamiętającego spojrzenia” Jacka Dehnela, w tym - o wspomnianych przeze mnie na początku przypadkach zestawiania estetyk danych obrazów z przestrzenią, w której powstały. W kontekście głównego tematu mojego artykułu warto jednak wspomnieć przede wszystkim o Poddaniu Bredy, „w którym to ja liryczne podróżuje pociągiem [znowu], a oglądany za oknem widok - nasyp kolejowy, las i suszące się pranie - utożsamia z tytułowym obrazem Diega Velazqueza" oraz o Apetycie: „Wieczór. Resztki po kolacji z Basią / nawet dość holenderskie” [J. Dehnel, Apetyt, cyt. za A. Kremer, tamże, s. 156], choć oczywiście drugi fragment nie dotyczy relacji z przestrzenią w takim sensie, w jakim dotyczą jej pozostałe teksty. Do Apetytu i Poddania Bredy można dodać jeszcze np. fragmenty Dziennika roku chrystusowego ciekawe o tyle, że "sztuczne filtry" nakłada się tutaj na krajobrazy kulturowe: „Długie, ciemne, rdzawo-czarne mury, okrągłe czerwone baszty, owinięte schodkami, puste dziedzińce - tu bardziej jeszcze niż gdzie indziej widać, że Indie to kraina de Chirica" [J. Dehnel, Dziennik roku chrystusowego, Warszawa 2015, s. 404]; na Islandii natomiast „widać nizinę z jeziorem, pejzaż zimowy Brueghla: kościółek, obok cmentarz z kilkoma pochylonymi kamiennymi nagrobkami i cztery bliźniacze domki" [tamże, s. 242; ten urywek świetnie koresponduje z wierszem Grochowiaka].

31 A. Kremer, "Patrzeć oczami artysty?", s. 158. Spojrzenie na okna pociągu jak na obrazy, jednak - w przeciwieństwie do utworów Dehnela i Hartwig - z zewnątrz, pojawia się z kolei np. w prozie Michała Cichego: „Okna wagonów wypełnione są zimnym blaskiem. W tych akwariach światła widać zielone siedzenia i metalowe półki. Każdy wagon jest jak objazdowa wystawa obrazów Edwarda Hoppera. Widać maleńkich ludzi w zielonkawej samotności. $\mathrm{O}$, mężczyzna w białej koszuli z podwiniętymi rękawami właśnie wstał, przeszedł z obrazu do obrazu i sięgnął na półkę po bordową walizkę" [M. Cichy, Pozwól rzece płynąć, Wołowiec 2017, s. 9]. Zarówno w Pozwól rzece ptynać, jak i w Zawsze jest dzisiaj manifestacje „pamiętającego spojrzenia” są liczne, chociażby: „Poprzedniego wieczoru wracałem Niemcewicza dziesięć minut przed zachodem i wpatrywałem się w słońce. Wyglądało jak rozgrzany miedziak opadający w chłodny błękit. Dookoła czerwonego kręgu oscylowały świetliste pajęczynki. Van Gogh malował je dosłownie" [M. Cichy, Zawsze jest dzisiaj, Wołowiec 2014, s. 5-6]. Zob. też M. Cichy, Pozwól rzece płynąć, s. 32, 76, 124; M. Cichy, Zawsze jest dzisiaj, s. 29, 63. Podczas konferencji Poetyki doświadczenia przestrzennego o obecności tego typu zestawień przestrzeni i sztuki w tekstach Cichego mówiła dr Magdalena Roszczynialska (referat Michała Cichego doświadczanie przestrzeni). 
w karminowych kubrakach i w spodniach niebieskich / i malować starannie, z paletą i z głową..." 32 . Warto zwrócić uwagę na ostatni wers przywołanego fragmentu, który jest chyba najbardziej wyrazistym przejawem totalności doświadczenia sztuki w tym tekście. Wydaje się bowiem, że owo „i malować starannie, z paletą i z głową" można uznać za próbę utożsamienia się z samym Brueglem, potwierdzenie jego słów z wiersza Grochowiaka.

Co jednak istotne, wszechogarniające "pamiętające odczuwanie" (trudno ograniczyć się tu do "pamiętającego spojrzenia”) zostaje w pewnym sensie unieważnione na początku ostatniej strofy tekstu: „I jakby nie opisać, po tych wszystkich Brueghlach / po wszystkich erudycjach - ta gwałtowność piękna”. Kremer widzi w tym fragmencie "refleksję na temat piękna, którego nie są $\mathrm{w}$ stanie opisać żadne odniesienia do sztuki i erudycyjne aluzje [...], choć chyba tylko literatura piękna gotowa jest się do tej porażki przyznać" ${ }^{33}$. Ważniejsze wydaje się jednak, że zacytowany urywek wiersza Dehnela $\mathrm{w}$ zestawieniu z całym tekstem przywodzi na myśl uwagę Filipa Lipińskiego:

Taka śladowa [tutaj, rzecz jasna, więcej niż śladowa] manifestacja obrazu, szczególny rodzaj tele-wizji, czyli widzenia na odległość, zakłóca konwencjonalny, przestrzenno-temporalny porządek, defamiliaryzuje świat, a przez to sprawia, że go zauważamy ${ }^{34}$.

A zatem wspominane „sztuczne filtry” czy „pamiętające spojrzenie” pozwalają dostrzec przestrzeń i pozornie błahe zdarzenia w niej zachodzące. „Wizualne geografie [dostępne dzięki «pamiętającemu spojrzeniu» - J. D.] są - jak pisze Rybicka - sposobami nadawania znaczenia widzianemu światu" 35. Choć Wiktorowi Szkłowskiemu, do którego odniósł się Lipiński, być może bliższe byłoby nazwanie owych „wizualnych geografii” raczej sposobami przydawania znaczenia (?) widzeniu świata - autor Sztuki jako chwytu odnotowuje przecież: „[p]o to więc, aby wrócić wrażenie życia, odczuwać rzeczy, aby czynić kamień kamiennym istnieje to, co nazywamy sztuką. Cel sztuki - dać odczucie rzeczy w formie widzenia, a nie pojmowania" 36 - wydaje się, że w przypadku „doświadczenia” przestrzeni

32 Zdaniem Aleksandry Kremer ten opis odsyła do konkretnego obrazu niderlandzkiego malarza, czyli Pochmurnego dnia [A. Kremer, "Patrzeć oczami artysty”, s. 159].

33 Tamże.

34 F. Lipiński, Hopper wirtualny, s. 208.

35 E. Rybicka, Geopoetyka, s. 158.

36 W. Szkłowski, Sztuka jako chwyt, przeł. R. Łużny, w: Teorie literatury XX wieku. Antologia, Kraków 2006, s. 100 (podkr. - J.D.). U Szkłowskiego to cel sztuki, który ma się realizować 
jej „rozumienia” (czy też pozorów rozumienia) i „widzenia” nie trzeba przeciwstawiać. Jedno z przywoływanych przez Ryszarda Nycza znaczeń pojęcia „doświadczenie", które chyba dość dobrze opisuje sens omawianych tu tekstów literackich, czyli

\begin{abstract}
„doznanie" - wskazuje właśnie na [...] fazę psychocielesnej „rejestracji” efektu zetknięcia ze światem. Podobnie jak w przypadku innych form językowych zawierających aspekty konkretne i abstrakcyjne, sprawdza się tu ogólna formuła, wedle której rozumienie świata wynika z naszej fizycznej łączności $\mathrm{z}$ otoczeniem, w którym żyjemy. Tak i tu zmysłowe doznanie wyprzedza i umożliwia opracowanie pojęciowe i językowe, lecz nie przesądza o jego konieczności ${ }^{37}$.
\end{abstract}

Teksty Hartwig i Dehnela pokazują, że chociaż owo „zmysłowe doznanie” jest poprzedzone doznaniem kulturowym, to staje się możliwe właśnie dzięki niemu: „sztuka jest mistrzynią natury - daje soczewkę, przez którą patrzymy na świat [i jesteśmy w stanie go dostrzec]" 38 .

w sztuce, jednak - rzecz jasna - nie musi się do sztuki ograniczać. Tak jest w rozważaniach Henri Bergsona (Zdrowy rozsądek i nauki klasyczne) następująco rekapitulowanych przez $\mathrm{Ny}-$ cza: „Wysoki prestiż sztuki w jego koncepcji bierze się najwyraźniej z przyznanego jej statusu wzorcowego przykładu wypełniania (sobie właściwymi środkami) tego najtrudniejszego zadania poznawczego dla nowoczesnej świadomości: sztuka (literatura) zmusza nas bowiem do odrzucenia rutyny percepcyjnej, automatyzmów języka, stereotypów pojęciowych (ucząc przy okazji, jak to robić), i w ten sposób «otwiera nam oczy na naturę». Poznanie artystyczne, dawniej traktowane jako niedoskonała, skażona dowolnością i własnymi słabościami forma poznania prawdziwego, staje się w Bergsonowskiej perspektywie modelem ludzkiego poznania w ogóle, w tym zwłaszcza poznania kulturowej rzeczywistości" [R. Nycz, Kulturowa natura, słaby profesjonalizm. Kilka uwag o przedmiocie poznania literackiego i statusie dyskursu literaturoznawczego, w: tegoż, Poetyka doświadczenia, s. 89]. Cień tego przekonania - oczywiście w innej formie, zawężonej - można dostrzec w refleksji Roberta B. Rileya, amerykańskiego profesora architektury. Wiąże się ono, już bezpośrednio, z omawianymi tu tekstami Hartwig oraz Dehnela: „Zapośredniczone [przeniesione z malarstwa, literatury, filmu, wyobrażone itp. - dop. J.D.] krajobrazy mogą kształtować nasze doświadczenie zewnętrznych krajobrazów, przyjemność, jaką z nich czerpiemy, wreszcie nasze krajobrazowe preferencje" [R. B. Riley, Pytania o wzrok, krajobraz i doświadczenie, przeł. M. Salwa, w: Krajobrazy. Antologia tekstów, s. 229].

37 R. Nycz, Trzy glosy o nowoczesności, doświadczeniu i literaturze, w: tegoż, Poetyka doświadczenia., s. 234 (podkr. - J.D.). Co zresztą ciekawe, wiersz Dehnela kończy wyznanie: „Od kogo taki prezent, tak niespodziewany / w dwudziestym trzecim roku: te krzewy tarniny / i głogu, te obłoki przypięte do ziemi? / Odpowiedź: «Od nikogo» byłaby niewdzięczna / i, na szczęście, zbyt prosta. Tarniny znikają”, które można chyba uznać za świadome „niedopracowanie pojęciowe i językowe" opisywanego doświadczenia.

38 Wypowiedź Stefana Hertmansa odnotowana w sprawozdaniu z Festiwalu Miłosza (2016 r.). Śledząc kroki poetów, [online] http://miloszfestival.pl/sledzac-kroki-poetow / [dostęp 12.09.2017]. 
Warto dodać jeszcze, że w zacytowanych uwagach Rybickiej („,nadawanie znaczenia widzianemu światu”) i Nycza („psychocielesna «rejestracja» efektu zetknięcia ze światem") można dostrzec dalekie echo rozpoznania Elżbiety Konończuk dotyczącego geopoetyki Kennetha White'a: „Istotą geopoetyki White'a jest zatem odkrywanie poetyki i poezji przestrzeni realizujące się $w$ «lirycznym zamieszkiwaniu świata», które polega na rozumieniu «pisarstwa ziemi», odczytywaniu świata-tekstu, słuchaniu jego muzyki" 39 .

Ciekawe, że owo „odczytywanie świata-tekstu” bywa możliwe dzięki „wspaniałemu językowi malarstwa” redukującemu „pojemny jak piekło język, którym pisane są wyroki sądów i powieści miłosne" 40 .

\section{Bibliografia}

Baranowska Małgorzata, Prywatna historia obrazów i krajobrazy, „Teksty Drugie” 2000, nr 5, s. 170-185.

Buczyńska-Garewicz Hanna, Miejsca, strony, okolice. Przyczynek do fenomenologii przestrzeni, Kraków: Universitas, 2006.

Cichy Michał, Pozwól rzece płynąć, Wołowiec: Czarne, 2017.

Cichy Michał, Zawsze jest dzisiaj, Wołowiec: Czarne, 2014.

Cortázar Julio, Gra w klasy, przeł. Z. Chądzyńska, Warszawa: Muza, 1998.

Cosgrove Denis E., Krajobraz i europejski zmyst wzroku - przygladanie się naturze, w: Krajobrazy. Antologia tekstów, oprac. B. Frydryczak, D. Angutek, Poznań: Wydawnictwo Poznańskiego Towarzystwa Przyjaciół Nauk, 2014, s. 79-109.

Dehnel Jacek, Dziennik roku chrystusowego, Warszawa: WAB, 2015.

Dehnel Jacek, Żywoty równoległe, Kraków: Biuro Literackie, 2004.

Dziadek Adam, Obraz jako interpretant: na przykładzie polskiej poezji wspótczesnej, „Pamiętnik Literacki" 2001, nr 92/2, s. 127-148.

Gautier Teophile, $\grave{A}$ trois paysagistes, http://www.unjourunpoeme.fr/poeme/a-troispaysagistes [dostęp 22.09.2017].

Hartwig Julia, Wiersze wybrane, Kraków: Wydawnictwo a5, 2010.

Herbert Zbigniew, Labirynt nad morzem, Warszawa: Zeszyty Literackie, 2000.

Herbert Zbigniew, Martwa natura z wędzidłem, Warszawa: Zeszyty Literackie, 2003.

Herbert Zbigniew, Wiersze zebrane, Kraków: Wydawnictwo a5, 2011.

Konończuk Elżbieta, W meandrach geopoetyki, „Teksty Drugie” 2015, nr 6, s. 213-228.

39 E. Konończuk, W meandrach geopoetyki, „Teksty Drugie” 2015, nr 6, s. 222.

40 Z. Herbert, Martwa natura $z$ wędzidtem, s. 110. 
Kremer Aleksandra, "Patrzeć oczami artysty?”. Dzieła sztuki w wierszach Jacka Dehnela, w: Ars in artibus. Recepcja sztuk plastycznych w muzyce, literaturze i filmie, red. A. Jezierska, D. Maciejewska, Wrocław: Studenckie Koło Naukowe Instytutu Historii Sztuki Uniwersytetu Warszawskiego, 2008, s. 154-167.

Lipiński Filip, Hopper wirtualny. Obrazy w pamiętającym spojrzeniu, Toruń: Wydawnictwo UMK, 2013.

Lisak-Gębala Dobrawa, Wizualne odskocznie. Wokót wspótczesnej polskiej eseistyki o malarstwie i fotografii, Kraków: Universitas, 2016.

Lorrain Claude, w: Oxford Dictionary of English. Second Edition, Revised [E-BOOK], eds. C. Soanes, A. Stevenson, Oxford: Oxford University Press, 2010.

Lowenthal David, Życie z krajobrazem i ogladanie krajobrazu, w: Krajobrazy. Antologia tekstów, oprac. B. Frydryczak, D. Angutek, Poznań: Wydawnictwo Poznańskiego Towarzystwa Przyjaciół Nauk, 2014, s. 111-139.

Marshall David, The Problem of the Picturesque, „Eighteenth Century Studies” 2002, nr 3, s. 413-437, http://www.jstor.org/stable/30054207 [dostęp 25.09.2017].

Nycz Ryszard, Poetyka doświadczenia. Teoria - nowoczesność - literatura, Warszawa: Wydawnictwo IBL PAN, 2012.

Poprzęcka Maria, Inne obrazy. Oko, widzenie, sztuka. Od Albertiego do Duchampa, Gdańsk: Słowo/Obraz Terytoria, 2008.

Price Uvedale, Esej o malowniczości, przeł. B. Frydryczak, Krajobrazy. Antologia tekstów, oprac. B. Frydryczak, D. Angutek, Poznań: Wydawnictwo Poznańskiego Towarzystwa Przyjaciół Nauk, 2014, s. 175-181.

Proust Marcel, W stronę Swanna, przeł. i wstępem opatrzył T. Boy-Żeleński, Warszawa: PIW, 1965.

Przyklenk Joanna, Esej podróżniczy jako świadectwo percepcji: na przykładzie eseistyki Zbigniewa Herberta, „Język Artystyczny” 2010, nr 14, s. 83-97.

Riley Robert B., Pytania o wzrok, krajobraz i doświadczenie, przeł. M. Salwa, w: Krajobrazy. Antologia tekstów, oprac. B. Frydryczak, D. Angutek, Poznań: Wydawnictwo Poznańskiego Towarzystwa Przyjaciół Nauk, 2014, s. 221-230.

Rybicka Elżbieta, Geopoetyka: przestrzeń i miejsce we wspótczesnych teoriach i praktykach literackich, Kraków: Universitas, 2014.

Rzepińska Maria, Siedem wieków malarstwa europejskiego, Wrocław: Ossolineum, 1986.

Szkłowski Wiktor, Sztuka jako chwyt, przeł. R. Łużny, w: Teorie literatury XX wieku. Antologia, Kraków: Znak, 2006, s. 95-111.

Śledząc kroki poetów, http://miloszfestival.pl/sledzac-kroki-poetow/ [dostęp 12.09. 2017].

Tomasik Wojciech, Ikona nowoczesności. Kolej w literaturze polskiej, Wrocław: Wydawnictwo Uniwersytetu Wrocławskiego, 2007.

Walcott Derek, Mapa Nowego Świata. Wiersze wybrane, wybór i red. M. Heydel, Kraków: Znak, 2008.

Walcott Derek, The Prodigal [fragm.], http://www.nytimes.com/2004/10/31/books/ chapters/the-prodigal.html?_r=0 [dostęp 20.09.2017]. 


\section{"A jednak oczyma / [m]oimi patrzycie...". On Experiencing Art Through Experiencing Space \\ Summary}

The paper discusses specific literary form of the cultural prefiguration of spatial perception - seeing landscapes and other spaces through the filter of one's experience of art. In the examined texts by Jacek Dehnel's and in Julia Hartwig's poems spaces perceived by the subject are juxtaposed and correlated with the afterimages of masterpiece paintings or memorable and identifiable styles of various artists.

Keywords: afterimage, Jacek Dehnel, Julia Hartwig, picturesque, space, art 